\title{
Cbf5p, the putative pseudouridine synthase of H/ACA-type snoRNPs, can form a complex with Gar1p and Nop10p in absence of Nhp2p and box H/ACA snoRNAs
}

\author{
ANTHONY K. HENRAS, ${ }^{1,2}$ REGINE CAPEYROU, ${ }^{1}$ YVES HENRY, $^{1}$ and MICHELE CAIZERGUES-FERRER ${ }^{1}$ \\ ${ }^{1}$ Laboratoire de Biologie Moléculaire Eucaryote, UMR5099, Centre National de la Recherche Scientifique (CNRS) and Université Paul \\ Sabatier, IFR109, 31062 Toulouse cedex 04, France, European Union
}

\begin{abstract}
Box C/D and box H/ACA small ribonucleoprotein particles (sRNPs) are found from archaea to humans, and some of these play key roles during the biogenesis of ribosomes or components of the splicing apparatus. The protein composition of the core of both types of particles is well established and the assembly pathway of box C/D sRNPs has been extensively investigated both in archaeal and eukaryotic systems. In contrast, knowledge concerning the mode of assembly and final structure of box $\mathrm{H} / \mathrm{ACA}$ sRNPs is much more limited. In the present study, we have investigated the protein/protein interactions taking place between the four protein components of yeast box H/ACA small nucleolar RNPs (snoRNPs), Cbf5p, Gar1p, Nhp2p, and Nop10p. We provide evidence that Cbf5p, Gar1p, and Nop10p can form a complex devoid of Nhp2p and small nucleolar RNA (snoRNA) components of the particles and that Cbf5p and Nop10p can directly bind to each other. We also show that the absence of any component necessary for assembly of box H/ACA snoRNPs inhibits accumulation of Cbf5p, Gar1p, or Nop10p, whereas Nhp2p levels are little affected.
\end{abstract}

Keywords: H/ACA snoRNPs; RNP structure; pre-rRNA processing

\section{INTRODUCTION}

Box C/D and box H/ACA small ribonucleoprotein particles (sRNPs) are found from archaea to humans and involved in nucleotide modification and/or processing of very diverse cellular RNAs (Weinstein and Steitz 1999; Kiss 2001, 2002; Bachellerie et al. 2002; Filipowicz and Pogačić 2002; Terns and Terns 2002; Decatur and Fournier 2003; Omer et al. 2003). Most of the known box C/D and box H/ACA sRNPs accumulate within the nucleolus and hence are termed small nucleolar RNPs (snoRNPs) (Balakin et al. 1996; Bachellerie and Cavaillé 1997; Smith and Steitz 1997; Kiss 2001, 2002). The majority of box C/D and box H/ACA snoRNPs, respectively, catalyze the methylation of the 2 'oxygen of specific riboses (Cavaillé et al. 1996; Kiss-László et al. 1996;

Reprint requests to: Yves Henry, Laboratoire de Biologie Moléculaire Eucaryote, UMR5099, CNRS and Université Paul Sabatier, IFR109, 118 route de Narbonne, 31062 Toulouse cedex 04, France, European Union; e-mail: henry@ibcg.biotoul.fr; fax: (33) 561335886.

${ }^{2}$ Present address: Department of Chemistry \& Biochemistry, UCLA, Box 951569, 607 Charles E. Young Drive East, Los Angeles, CA 900951569, USA.

Article published online ahead of print. Article and publication date are at http://www.rnajournal.org/cgi/doi/10.1261/rna.7770604.
Tycowski et al. 1996) or the isomerization of specific uridines into pseudouridines (Ganot et al. 1997a; $\mathrm{Ni}$ et al. 1997) within preribosomal RNAs. In addition, some snoRNPs in Schizosaccharomyces pombe and higher eukaryotes are responsible for the 2 'O-ribose methylation of certain nucleotides of spliceosomal U6 snRNA (Tycowski et al. 1998; Ganot et al. 1999; Zhou et al. 2002). A subset of snoRNPs, the box C/D snoRNPs U3 (Hughes and Ares 1991; Beltrame and Tollervey 1992, 1995), U8 (Peculis and Steitz 1993; Peculis 1997), U14 (Li et al. 1990; Liang and Fournier 1995), U22 (Tycowski et al. 1994), and the box H/ACA snoRNPs snR10 (Tollervey 1987) and snR30/U17 (Morrissey and Tollervey 1993; Atzorn et al. 2004) are required for certain cleavage events during maturation of prerRNAs. More recently, sRNPs displaying characteristic features of box C/D and/or box H/ACA snoRNPs (see below) have been found to accumulate in nucleoplasmic Cajal bodies and hence have been termed small Cajal body-specific (sca) RNPs (Jády and Kiss 2001; Darzacq et al. 2002; Jády et al. 2003). These scaRNPs catalyze nucleotide modifications within RNA polymerase II transcribed spliceosomal snRNAs. Box C/D and box H/ACA sRNP-directed nucleotide modifications are not restricted to pre-rRNAs and spliceosomal snRNAs (Bachellerie et al. 2002). Indeed, 
box C/D sRNPs have been characterized in archaea that direct methylation of tRNAs (Clouet d'Orval et al. 2001; Dennis et al. 2001), box H/ACA sRNPs have been found in trypanosomes that could direct pseudouridylation of spliced leader RNAs (Liang et al. 2002), and some brainspecific snoRNPs may modify mRNAs in mammals (Cavaillé et al. 2000).

All box C/D sRNPs contain a small RNA featuring the conserved $\mathrm{C}$ and $\mathrm{D}$ boxes placed close to the mature termini of the molecule as well as related, but often more degenerate, internal motifs termed $\mathrm{C}^{\prime}$ and $\mathrm{D}^{\prime}$ (Kiss-László et al. 1998). The RNA component of canonical box H/ACA sRNPs adopts a conserved secondary structure containing two irregular hairpins possessing an internal loop (Ganot et al. 1997b). These hairpins are separated by a singlestranded hinge region containing the conserved $\mathrm{H}$ box and followed by a single-stranded tail containing the conserved ACA box always located 3 nucleotides upstream from the $3^{\prime}$ end of the molecule (Balakin et al. 1996; Ganot et al. 1997b). However, highly related RNAs probably involved in pseudouridylation have been found that contain a single hairpin and lack an $\mathrm{H}$ box (in archaea and trypanosomes) (Liang et al. 2001, 2002; Tang et al. 2002; Rozhdestvensky et al. 2003) or that contain three or more hairpins (in archaea and mammals) (Kiss et al. 2002; Tang et al. 2002; Rozhdestvensky et al. 2003). ScaRNPs often contain hybrid RNAs possessing features of both box C/D and box H/ACA RNAs (Jády and Kiss 2001; Darzacq et al. 2002). In addition, the RNA components of scaRNPs, scaRNAs, contain a conserved element termed the $\mathrm{CAB}$ box that mediates specific retention of these particles within Cajal bodies (Richard et al. 2003).

Four highly conserved polypeptides constitute the protein core of the particles: Snu13p (or 15.5-kDa protein in humans) (Watkins et al. 2000), Nop56p, Nop58p (Gautier et al. 1997; Watkins et al. 1998b; Wu et al. 1998; Lafontaine and Tollervey 1999; Lyman et al. 1999; Lafontaine and Tollervey 2000; Newman et al. 2000), and Nop1p (Tollervey et al. 1991) (fibrillarin in humans), (Tyc and Steitz 1989) in the case of box C/D sRNPs and Nop10p (Henras et al. 1998; Pogačić et al. 2000; Yang et al. 2000), Nhp2p (Henras et al. 1998; Watkins et al. 1998a; Pogačić et al. 2000; Yang et al. 2000), Garlp (Girard et al. 1992; Balakin et al. 1996; Ganot et al. 1997b; Dragon et al. 2000; Yang et al. 2000), and Cbf5p (NAP57 in rodents, Dyskerin in humans) (Lafontaine et al. 1998; Watkins et al. 1998a; Mitchell et al. 1999; Zebarjadian et al. 1999; Yang et al. 2000) in the case of H/ACA sRNPs. Nop1p and Cbf5p are related to methyl transferases (Niewmierzycka and Clarke 1999) and pseudouridine synthases (Hoang and Ferre-D'Amare 2001), respectively, and hence are believed to carry the catalytic activity of the particles. Snu13p and its archaeal homolog, the ribosomal protein L7Ae, have been shown to bind to the so-called kinkturn motif formed by pairing of the terminal $\mathrm{C}$ and $\mathrm{D}$ boxes and flanking elements (Watkins et al. 2000; Kuhn et al.
2002; Omer et al. 2002; Watkins et al. 2002; Marmier-Gourrier et al. 2003). Reconstitution experiments using purified archaeal proteins have shown that binding of L7Ae to the kink-turn motif is a prerequisite for subsequent binding of Nop5p (the single homolog of both eukaryotic Nop56p and Nop58p) and archaeal fibrillarin. Both the external C/D and internal $\mathrm{C}^{\prime} / \mathrm{D}^{\prime}$ motifs of archaeal sRNAs constitute binding sites for L7Ae and hence allow subsequent assembly of Nop5p and fibrillarin, leading to the production of symmetric particles (Omer et al. 2002; Bortolin et al. 2003; Rashid et al. 2003; Tran et al. 2003). In contrast, eukaryotic box C/D sRNPs are asymmetric because the $15.5 \mathrm{kDa}$ protein binds only to the terminal C/D motif (Szewczak et al. 2002) and cross-linking experiments in Xenopus indicate that Nop56p and Nop58p interact only with the $\mathrm{C}^{\prime} / \mathrm{D}^{\prime}$ and C/D motifs, respectively (Cahill et al. 2002). Purified box H/ACA snoRNPs can faithfully direct specific uridine to pseudouridine conversions in vitro (Wang et al. 2002). So far however, no in vitro reconstitution experiments of box H/ACA sRNPs have been reported, and little is known regarding the structure of the mature particles. Archaeal H/ACA sRNAs contain kink-turn motifs that constitute binding sites for L7Ae (Rozhdestvensky et al. 2003). The situation is different in eukaryotes because most eukaryotic box H/ACA snoRNAs seem to lack a kink-turn motif (Rozhdestvensky et al. 2003) and Nhp2p, the eukaryotic counterpart of L7Ae, binds RNA with little sequence specificity in vitro (Henras et al. 2001; Wang and Meier 2004).

In the present study, we have investigated the structure of yeast H/ACA snoRNPs by stepwise disruption, using biochemical approaches, of purified yeast H/ACA snoRNPs. Our results suggest that the four proteins, Cbf5p, Garlp, Nhp2p, and Nop10p, can remain associated under conditions that destabilize their interactions with the RNA components of the particles, arguing that a network of proteinprotein interactions takes place between these four core factors. Moreover, we show that Cbf5p, Gar1p, and Nop10p form a complex, likely involving hydrophobic interactions, and that Cbf5p and Nop10p interact directly within this subcomplex.

\section{RESULTS AND DISCUSSION}

\section{Cbf5p, Gar1p, and Nop10p can form a complex that persists at high salt concentrations}

Our attempts to reconstitute H/ACA snoRNPs in vitro from purified components have so far been hampered by the fact that we have been unable to obtain sufficient quantities of pure recombinant yeast Cbf5p. To circumvent this problem, we adopted the opposite approach to study H/ACA snoRNP structure, that is, we performed "disruption studies". We made use of a yeast strain expressing one protein component of H/ACA snoRNPs, Cbf5p, containing an IgG- 
binding tag (ZZ-tag) derived from Staphylococcus aureus protein A. Such tagged H/ACA snoRNPs have been bound to an IgG-sepharose column. After extensive washing, we then applied to this column buffers containing increasing concentrations of $\mathrm{KCl}(0.8,1,1.2,1.5,2$, and $3 \mathrm{M} \mathrm{KCl})$. The interaction between the tag of Cbf5p and the IgGs of the column was finally disrupted by addition of a buffer containing $4 \mathrm{M} \mathrm{MgCl}_{2}$. The presence in the eluted fractions of various H/ACA core proteins and snoRNAs was tested by Western (Fig. 1A) and Northern (Fig. 1B) blot analyses. In addition to tagged Cbf5p, the other three core protein components of H/ACA snoRNPs, that is, Garlp, Nhp2p, and Nop10p, remained bound to the column until the buffer containing $4 \mathrm{M} \mathrm{MgCl}_{2}$ was applied, except for a very small fraction of Nhp2p which was washed off at intermediate $\mathrm{KCl}$ concentrations (Fig. 1A). The proportion of H/ACA snoRNAs that remained bound to the column up to addition of the buffer containing $4 \mathrm{M} \mathrm{MgCl}_{2}$ was more variable (Fig. 1B). The bulk of snR30 was only released after addition of this buffer. In contrast, the elution peak of snR42 was centred on the 1.5 and $2 \mathrm{M} \mathrm{KCl}$ fractions. snR10 dis-

A
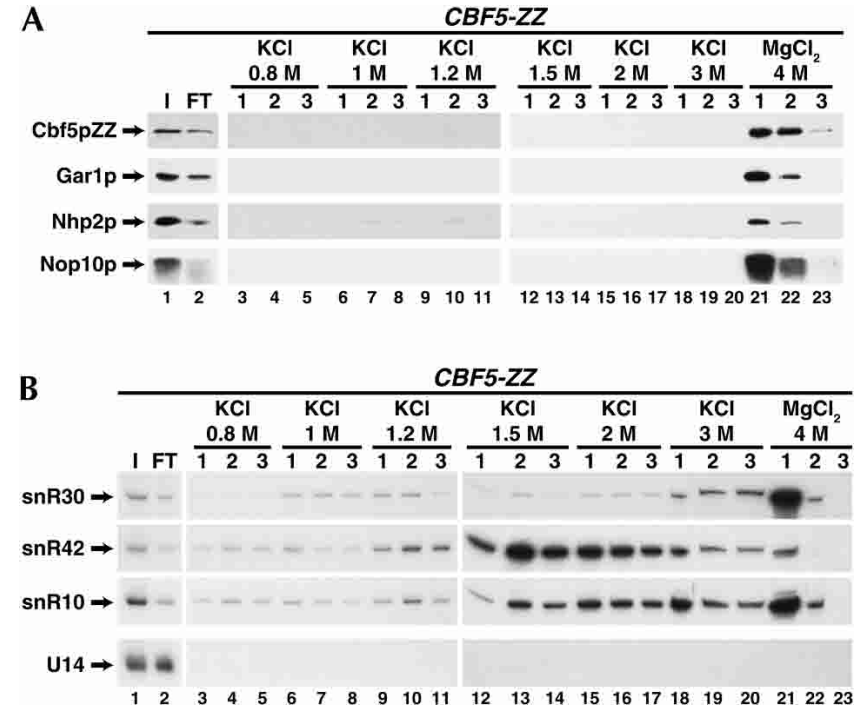

FIGURE 1. Interactions between H/ACA snoRNP proteins are resistant to high $\mathrm{KCl}$ concentrations. An extract was prepared from a strain expressing Cbf5p tagged with an IgG-binding domain (Cbf5p-ZZ) and loaded on an IgG-sepharose column. Buffers containing increasing concentrations of $\mathrm{KCl}(0.8 \mathrm{M}$, lanes $3-5 ; 1 \mathrm{M}$, lanes $6-8$; $1.2 \mathrm{M}$, lanes 9-11; $1.5 \mathrm{M}$ lanes 12-14; $2 \mathrm{M}$, lanes 15-17; $3 \mathrm{M}$, lanes 18-20) followed by a buffer containing $4 \mathrm{M} \mathrm{MgCl}_{2}$ (lanes 21-23) were applied to the column and eluting fractions were collected each time $(1,2,3)$. An aliquot of each fraction was used for protein extraction and Western analysis $(A)$, another for RNA extraction and Northern analysis $(B)$. Proteins and RNAs were also extracted from aliquots of the initial extract (I, lanes 1) and flow through fraction (FT, lanes 2). (A) Proteins were separated by SDS-PAGE and transferred to cellulose membranes. Specific proteins were detected by ECL using either Dakko rabbit PAP, polyclonal anti-Garlp, anti-Nhp2p or anti-Nop10p sera. (B) RNAs were separated on $6 \%$ polyacrylamide denaturing gels and transferred to nylon membranes. Specific snoRNAs were detected using antisense oligodeoxynucleotide probes. played an intermediate elution profile, a substantial proportion of this RNA being released by addition of buffers containing $2 \mathrm{M}$ and $3 \mathrm{M} \mathrm{KCl}$. These results show that H/ACA snoRNP cohesion is resistant to high $\mathrm{KCl}$ concentrations. Moreover, they suggest that the four core H/ACA snoRNP proteins can interact even when their interactions with the snoRNA components of the particles are destabilized.

Because treatment with high $\mathrm{KCl}$ concentrations essentially failed to dissociate the four H/ACA snoRNP proteins from one another, we next tested the effects of different $\mathrm{MgCl}_{2}$ concentrations. Particles containing either Cbf5p, Gar1p, Nhp2p, or Nop10p tagged with an IgG-binding domain were bound to IgG-sepharose columns, and buffers containing $\mathrm{MgCl}_{2}$ at increasing concentrations $(0.5 \mathrm{M}, 2 \mathrm{M}$, $4 \mathrm{M}$ ) were applied. The presence in the eluted fractions of various H/ACA proteins and snoRNAs was assessed by Western blot analyses (Fig. 2A; data not shown) and Northern blot analyses (Fig. 2B; data not shown) or $3^{\prime}$-end labeling of RNAs with ${ }^{32} \mathrm{P}[\mathrm{pCp}$ ( Fig. $2 \mathrm{C}$ ). When Cbf5p is the tagged component, it remains bound to the column via its tag until a buffer containing $4 \mathrm{M} \mathrm{MgCl}_{2}$ is applied (Fig. 2A, lanes 9-11), as expected. Nhp2p is released as soon as a buffer containing $0.5 \mathrm{M} \mathrm{MgCl}_{2}$ is applied (Fig. 2A, lane 3). In contrast, Garlp and Nop10p do not dissociate from the column after $0.5 \mathrm{M}$ and $2 \mathrm{M} \mathrm{MgCl}_{2}$ addition (Fig. $2 \mathrm{~A}$, lanes 3-8) and are only eluted after $4 \mathrm{M} \mathrm{MgCl}_{2}$ addition, together with tagged Cbf5p (Fig. 2A, lanes 9-11). Identical protein elution profiles are obtained if strains expressing tagged Garlp or tagged Nop10p are used (data not shown). When an extract containing tagged Nhp2p is used, this protein remains bound to the column via its tag until $4 \mathrm{M} \mathrm{MgCl}_{2}$ addition, as expected (Fig. 2A, lanes 20-22), while Garlp and Nop10p dissociate together from the column after $0.5 \mathrm{M}$ $\mathrm{MgCl}_{2}$ addition (Fig. 2A, lane 14-the presence of Cbf5p could not be assessed by Western analysis for lack of an anti-Cbf5p serum, but a protein migrating as expected for Cbf5p could be detected by Coomassie staining). Northern analyses and ${ }^{32} \mathrm{P}[\mathrm{pCp}]$ labeling of RNAs show that H/ACA snoRNAs are eluted after $0.5 \mathrm{M} \mathrm{MgCl}_{2}$ and $2 \mathrm{M} \mathrm{MgCl}_{2}$ addition, whatever the identity of the tagged protein component (Fig. 2B,C, lanes 3-8,14-19). Importantly, nonH/ACA RNAs are found only in the initial flow through fractions (Figs. 1B, 2B, U14 control; data not shown) demonstrating that only bona fide H/ACA snoRNPs are specifically retained on our affinity columns.

These data suggest that Cbf5p, Gar1p, and Nop10p can form a complex in the absence of H/ACA snoRNAs and Nhp2p. It was nevertheless necessary to confirm that Cbf5p, Garlp, and Nop10p form a complex devoid of other protein components. To that end, the disruption experiment described above was repeated using an extract containing ZZtagged Cbf5p, a fraction collected after addition of a buffer containing $4 \mathrm{M} \mathrm{MgCl}_{2}$ was dialyzed to remove excess $\mathrm{MgCl}_{2}$, and the proteins were concentrated (see Materials and Methods for details). Proteins present in the concen- 
A

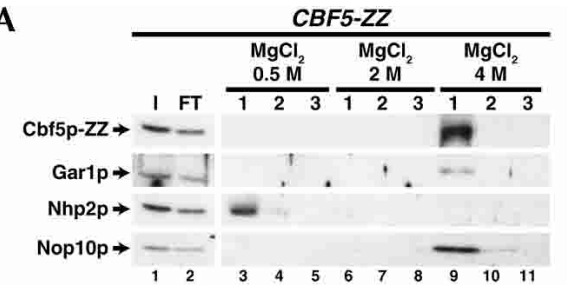

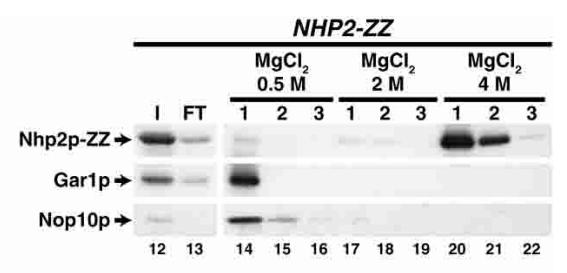

B

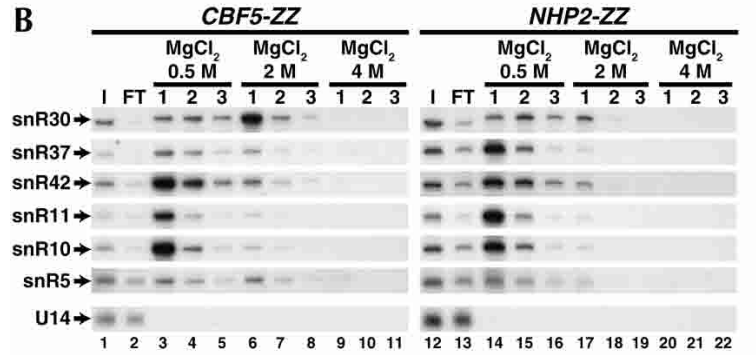

C

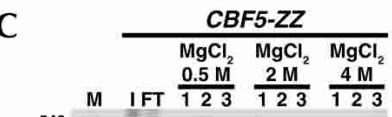

NHP2-ZZ

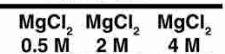

$\frac{0.5 \mathrm{M}^{2}}{123} \frac{2 \mathrm{M}^{2}}{123} \frac{4 \mathrm{M}^{2}}{123}$

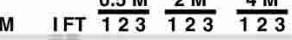

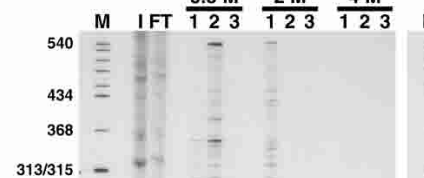

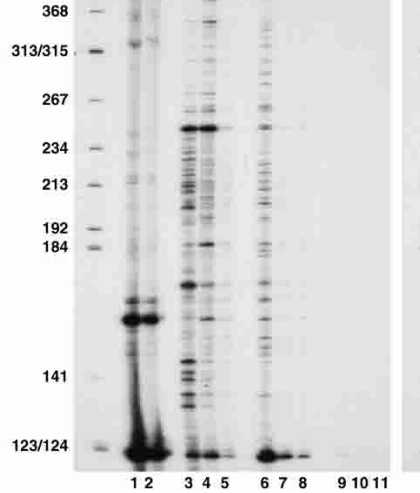

D

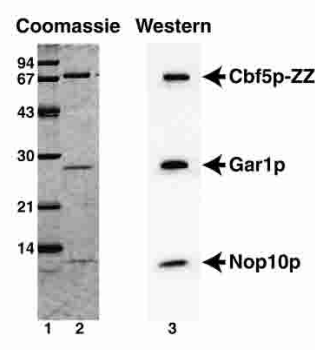

FIGURE 2. Cbf5p, Garlp, and Nop10p form a complex. Extracts were prepared from strains expressing Cbf5p-ZZ (lanes 1-11) or Nhp2p-ZZ (lanes 12-22) and were loaded on IgGsepharose columns. Buffers containing increasing concentrations of $\mathrm{MgCl}_{2}(0.5 \mathrm{M}$, lanes 3-5 and 14-16; $2 \mathrm{M}$, lanes 6-8 and 17-19; $4 \mathrm{M}$, lanes 9-11 and 20-22) were successively applied to the columns and eluting fractions were collected each time $(1,2,3)$. An aliquot of each fraction was used for protein extraction and Western analysis $(A)$, another for RNA extraction and Northern analysis $(B)$ or ${ }^{32} \mathrm{P}[\mathrm{pCp}] 3^{\prime}$ end-labeling of RNAs $(C)$. Proteins and RNAs were also extracted from aliquots of the initial extracts $(\mathrm{I}$, lanes 1,12$)$ and flow through fractions (FT, lanes 2,13). (M) Molecular weight markers (pBR322 digested with HaeIII-TaqI). Western and Northern analyses were performed as described in the legend of Figure 1. $3^{\prime}$-end-labeled RNAs were separated on $6 \%$ polyacrylamide sequencing gels. (D) Purification of the Cbf5p-ZZ/ Garlp/Nop10p complex. An extract prepared from the Cbf5p-ZZ expressing strain was treated as described above. A fraction collected after addition of a buffer containing $4 \mathrm{M} \mathrm{MgCl}_{2}$ addition was dialyzed and the proteins were concentrated on a microcon. Proteins from aliquots of the concentrated sample were separated by SDS-PAGE and either stained with Coomassie blue (lane 2) or subjected to Western blot analysis (lane 3). (Lane 1) Molecular weight protein markers.

trated sample were separated by SDS-PAGE and stained with Coomassie blue (Fig. 2D, lane 2). Only three polypeptides could be detected, corresponding to tagged Cbf5p, Garlp, and Nop10p as indicated by Western analyses (Fig. 2D, lane 3).

\section{Cbf5p and Nop10p can bind to each other}

In the absence of Garlp, incomplete H/ACA snoRNPs are still assembled but cannot interact with preribosomal complexes (Bousquet-Antonelli et al. 1997). We next investigated the effects of the absence of Garlp on the stability of H/ACA snoRNPs. To that end, we used a strain that expresses Cbf5p-ZZ and a form of Garlp that is degraded at $37^{\circ} \mathrm{C}$. At that temperature, this strain produces incomplete H/ACA snoRNPs lacking Garlp (Bousquet-Antonelli et al. 1997 and data not shown). Extracts from this strain grown at $37^{\circ} \mathrm{C}$ were used in $\mathrm{KCl}$ gradient experiments as previously described. Similar to what was seen in the case of wild-type particles, the bulk of Nop10p remains strongly bound to the column until the interaction between tagged Cbf5p and the column is disrupted. Nhp2p is much more readily released as witnessed by its detection in most fractions (data not shown). The relative trends of H/ACA snoRNA elutions are similar to those detected in the case of wild-type particles, that is, snR42 and snR10 are more easily released than snR30. However, for each snoRNA considered, significant elution begins at lower salt concentrations compared to the wild-type case (data not shown). We conclude that lack of Garlp reduces the cohesion of H/ACA snoRNPs. However, the interaction between Cbf5p and Nop10p seems little affected. To investigate this point further, we then performed a disruption experiment, again using a yeast cell extract expressing tagged Cbf5p and devoid of Garlp, but this time applying to the column buffers containing increasing $\mathrm{MgCl}_{2}$ concentrations. We confirmed by Northern analyses and ${ }^{32} \mathrm{P}[\mathrm{pCp}]$ labeling of RNAs that $0.5 \mathrm{M}$ and $2 \mathrm{M} \mathrm{MgCl}_{2}$ treatment removed essentially all H/ACA snoRNAs (Fig. 3B,C, lanes 3-8), as seen in the wild-type case. Western analysis shows that Nhp2p is eluted after $0.5 \mathrm{M}$ $\mathrm{MgCl}_{2}$ addition, as expected (Fig. 3A, lane 3). This is also the case for a fraction of Nop10p (Fig. 3A, lane 3). However, the bulk of Nop10p is eluted together with tagged Cbf5p after $4 \mathrm{M} \mathrm{MgCl}_{2}$ addition (Fig. 3A, lane 9). These data 
A

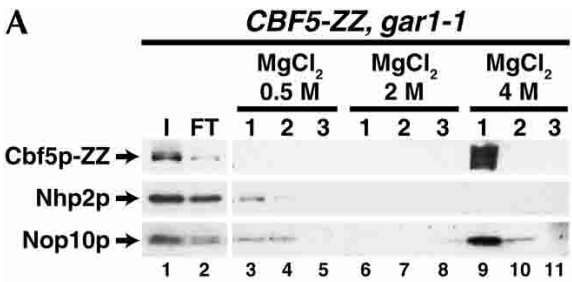

B

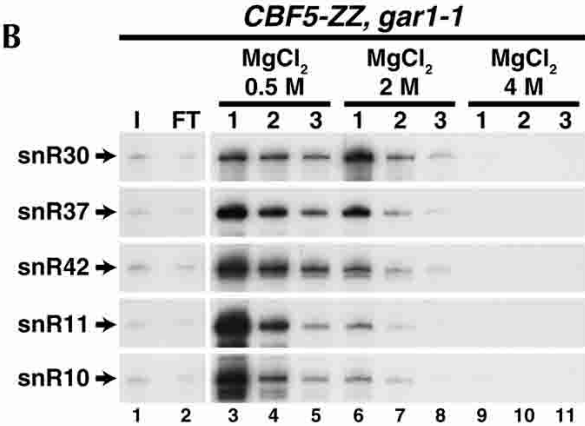

C

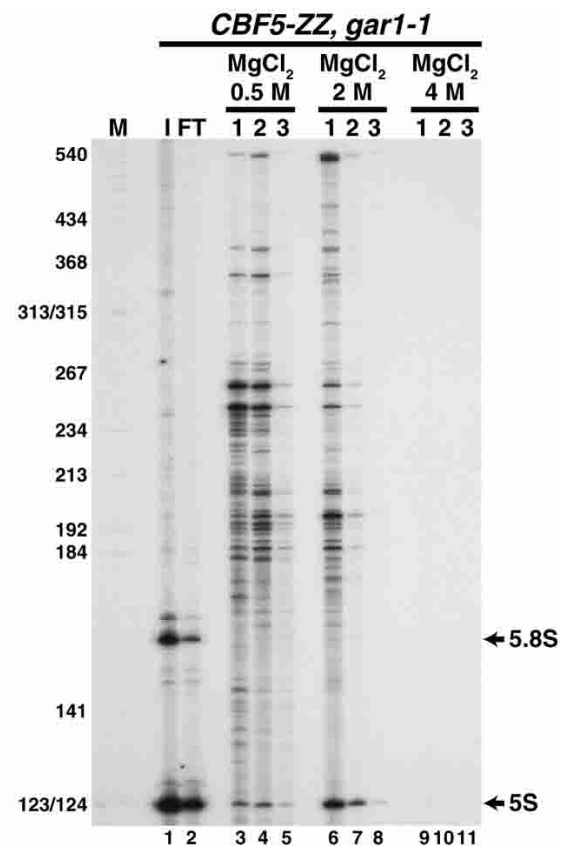

FIGURE 3. Cbf5p and Nop10p interact directly. A yeast strain (CBF5-ZZ, gar1-1) expressing Cbf5p-ZZ and a thermo-sensitive version the Garlp protein was grown at $25^{\circ} \mathrm{C}$, then transferred at $37^{\circ} \mathrm{C}$ for $4 \mathrm{~h}$ to induce the degradation of Garlp. A total extract was then prepared and loaded on an IgG-sepharose column. Buffers containing increasing concentrations of $\mathrm{MgCl}_{2}(0.5 \mathrm{M}$, lanes 3-5; $2 \mathrm{M}$, lanes 6-8; 4 M, lanes 9-11) were applied to the column and eluting fractions were collected each time $(1,2,3)$. The protein and RNA contents of aliquots of the input extract (I, lane 1), flow-through (FT, lane 2), and eluting fractions (lanes 3-11) were assessed by Western blot analysis $(A)$ and Northern blot analysis $(B)$ or ${ }^{32} \mathrm{P}[\mathrm{pCp}] 3^{\prime}$ end labeling of RNAs $(C)$, as described in the legends of Figures 1 and 2.

strongly suggest that Cbf5p and Nop10p can directly interact in the absence of any other H/ACA snoRNP component.

\section{Accumulation of Cbf5p, Gar1p, or Nop10p is strongly reduced by lack of any protein component required for assembly of H/ACA snoRNPs}

It has previously been reported that steady-state levels of Garlp and H/ACA snoRNAs are strongly diminished when Cbf5p, Nhp2p, or Nop10p are depleted (Henras et al. 1998; Lafontaine et al. 1998; see also Fig. 4B). Because Cbf5p, Garlp, and Nop10p seem to form a complex, we wondered whether accumulation of Cbf5p or Nop10p might likewise be very sensitive to depletion of another protein component of H/ACA snoRNPs. Data presented in Figure 4A show that this is indeed the case. Accumulation of Nop10p is strongly diminished following Cbf5p (Fig. 4A, lanes 1-4) or Nhp2p (Fig. 4A, lanes 5-8) depletion. Likewise, normal accumulation of Cbf5p depends on the presence of Nhp2p (Fig. 4A, lanes 5-8) or Nop10p (Fig. 4A, lanes 9-12). In contrast, Nhp2p levels are only marginally decreased by depletion of either Cbf5p (Fig. 4A, lanes 1-4) or Nop10p (Fig. 4A, lanes 9-12).

\section{Conclusions}

In this study, we have attempted to investigate the proteinprotein interactions taking place within H/ACA snoRNPs by treating wild-type particles or particles lacking Garlp with buffers containing increasing $\mathrm{KCl}$ or $\mathrm{MgCl}_{2}$ concentrations. Interactions between the four core H/ACA snoRNP proteins Cbf5p, Gar1p, Nhp2p, and Nop10p persist at high $\mathrm{KCl}$ concentrations which induce the dissociation from the protein core of a substantial proportion of abundant H/ACA snoRNAs such as snR10 and snR42. Such data are a hint that these four proteins can form a complex in the absence of RNA. Treatment of H/ACA snoRNPs with increasing concentrations of $\mathrm{MgCl}_{2}$ has a more drastic effect on the stability of the particles. Addition of $2 \mathrm{M} \mathrm{MgCl}_{2}$ to particles retained on affinity columns via tagged Cbf5p, tagged Garlp, or tagged Nop10p allowed us to separate a subcore consisting of Cbf5p, Garlp, and Nop10p from Nhp2p and essentially any H/ACA snoRNA tested. The resistance of the Cbf5p/Gar1p/Nop10p complex to high $\mathrm{MgCl}_{2}$ concentrations suggests that hydrophobic interactions significantly contribute to the formation and/or stability of this complex. Lack of Garlp does not prevent assembly of incomplete H/ACA snoRNPs (Bousquet-Antonelli et al. 1997; this study). However, our data show that the absence of Garlp somewhat destabilizes interactions between the remaining H/ACA snoRNP components. Nhp2p and the H/ACA snoRNAs tested dissociate more readily from Cbf5p and Nop10p when the $\mathrm{KCl}$ gradient is applied. Nevertheless, our data show that Cbf5p, the likely pseudouridine synthase, and Nop10p can interact when Garlp is absent and that this interaction is maintained in a buffer containing 2 


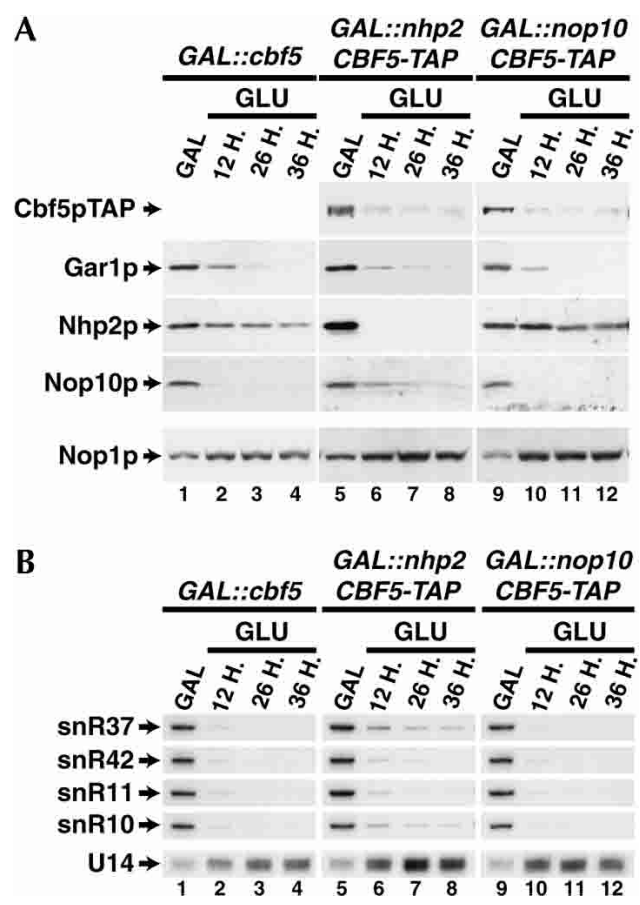

FIGURE 4. Accumulation of H/ACA snoRNP proteins when expression of one component of the particles is inhibited. GAL::cbf5 (lanes 1-4), GAL::nhp2/CBF5-TAP (lanes 5-8), or GAL::nop10/CBF5-TAP (lanes 9-12) strains were grown in galactose-containing medium (lanes 1,5,9), then transferred to glucose-containing medium to repress transcription of the genes under the control of the GAL promoter. Samples were collected after $12 \mathrm{~h}$ (lanes 2,6,10), $26 \mathrm{~h}$ (lanes $3,7,11$ ) or $36 \mathrm{~h}$ (lanes $4,8,12$ ) of growth in glucose medium. Total proteins or RNAs were extracted from these samples and analyzed by Western blot $(A)$ or Northern blot $(B)$, as described in the legend of Figure 1. Noplp was detected using purified anti-fibrillarin antibodies.

$\mathrm{M} \mathrm{MgCl}_{2}$. Very recently, Wang and Meier (2004) reported experiments performed with in vitro transcribed mammalian H/ACA snoRNP proteins that led them to the conclusions that NAP57 can independently interact with GAR1 or NOP10 and that NHP2 can only interact with a preformed NAP57-NOP10 complex. These conclusions are entirely compatible with our findings in yeast. Another interesting aspect emanating from our studies is that different H/ACA snoRNAs display somewhat different elution profiles in response to increasing salt concentrations. This observation suggests that the stability of the interactions between the protein core and the RNA component of the particles varies depending on the H/ACA snoRNA considered.

It is known that, in vivo, accumulation of H/ACA snoRNPs requires the participation of the nucleoplasmic Naflp protein (Dez et al. 2002; Fatica et al. 2002; Yang et al. 2002). Naflp can interact separately in vitro with Cbf5p, Nhp2p, and H/ACA snoRNAs (Fatica et al. 2002). Moreover, Naf1p displays a positive double-hybrid interaction with the carboxy-terminal domain of the large subunit of RNA polymerase II (Fatica et al. 2002). Hence it was proposed that Naflp recruits H/ACA snoRNP proteins to nascent H/ACA pre-snoRNAs (Fatica et al. 2002). It is tempt- ing to speculate that Naf1p could deliver Nhp2p and a hypothetical Cbf5p/Gar1p/Nop10p subcore to nascent H/ACA pre-snoRNAs. Halting production of Naflp results in a strong inhibition of the accumulation of Cbf5p, Garlp, and Nop10p (Dez et al. 2002). One possibility is that, when assembly of H/ACA snoRNPs is blocked due to lack of Naflp, a preformed Cbf5p/Garlp/Nop10p complex is targeted for degradation. The same phenomenon would presumably occur when productive assembly of H/ACA snoRNPs is inhibited by the depletion of Nhp2p. Depletion of Cbf5p or depletion of Nop10p could destabilize or altogether inhibit interactions between the remaining two protein components of the complex, leading to their selective degradation. In contrast, lack of Garlp would be envisaged not to prevent the interaction between Cbf5p and Nop10p. Thus, even when Garlp is absent, Naflp could recruit, by binding to Cbf5p, a preformed Cbf5p/Nop10p complex and promote effective assembly of incomplete H/ACA snoRNPs.

\section{MATERIALS AND METHODS}

\section{Strains, media, and plasmids}

Strains used in salt gradient analyses were the following. The strain expressing Nhp2p-ZZ was YO346 described by Henras et al. (2001); the strain expressing Cbf5p-ZZ was YDL524 described by Lafontaine et al. (1998). A yeast strain (gar1.1/pFH70) expressing Cbf5p-ZZ and a version of the Garlp protein (encoded by the mutant garl.1 allele; Bousquet-Antonelli et al. 1997) degraded at $37^{\circ} \mathrm{C}$ was obtained by transforming strain YO127 [Mat $\alpha$, ade2, ade3, can1, his4-260, leu2, lys2, trp1.1, tyr7.1, ura3, gar1::LEU2/ pJPG224 (pgar1.1)] possessing the gar1.1 allele with plasmid pFH70. pFH70 was produced by PCR amplifying the CBF5 open reading frame with oligonucleotides Cbf5\#27 (5'-CCCCCCC CAGATCTTTCTTAGATTTCTTAGATTTCTTTTCCTC-3') and Cbf5\#30 (5' -CCCCCAGATCTAATGTCAAAGGAGGATTTCGTT ATTAAGCC- $3^{\prime}$ ), digesting the PCR product with BglII and inserting the digested fragment into yeast expression vector pHA113 (Henras et al. 2001) cut with BamHI.

Depletion of Cbf5p, Nhp2p, or Nop10p was obtained using strains YDL521 (Lafontaine et al. 1998), GAL::nhp2/CBF5-TAP, or GAL::nop10/CBF5-TAP, respectively. The latter two strains were obtained by transforming strains GAL::nhp2 (Henras et al. 1998) or GAL:: nop10 (Henras et al. 1998) with a CBF5-TAP cassette. This cassette, flanked on the $5^{\prime}$ side by the last $48 \mathrm{nt}$ of the CBF5 open reading frame and on the $3^{\prime}$ side by a segment of the CBF5 terminator and containing the TAP-tag sequence followed by a TRP1 marker from Kluyveromyces lactis, was PCR amplified using plasmid pBS1479 (Rigaut et al. 1999), oligonucleotides TAPCbf5/1 (5'-TCTGAAGACGGTGATTCTGAGGAAAAGAAATCTAA GAAATCTAAGAAAtccatggaaaagagaag-3') and TAP-Cbf5/2 (5'-T CTAATCTAATAATAGAAAAAGTTTTTTGAAAAAAAGAAAGC TGTTAtacgactcactataggg-3').

Saccharomyces cerevisiae strains were grown either in YP medium ( $1 \%$ yeast extract, $1 \%$ peptone) supplemented with either $2 \%$ galactose, $2 \%$ raffinose, $2 \%$ sucrose, or $2 \%$ galactose, or $2 \%$ glucose as carbon sources or in YNB medium $(0.17 \%$ yeast nitro- 
gen base, $\left.0.5 \%\left(\mathrm{NH}_{4}\right)_{2} \mathrm{SO}_{4}\right)$ supplemented with $2 \%$ glucose and the required amino acids. Escherichia coli $\mathrm{DH} 5 \alpha$ strain $\left[F^{\prime}\right.$, endA1, hsdr17 $\left(r_{k}^{-} m_{k}^{+}\right)$, supE44, thi-1, recA1, gyrA (Nal $\left.{ }^{r}\right)$, relA1, $\Delta$ (lacIZYA-argF)U169, deoR, ( $\phi 80$ dlac $\Delta($ lacZ)M15)] grown on LB ( $1 \%$ bacto-tryptone, $0.5 \%$ bacto-yeast extract, $1 \% \mathrm{NaCl}$ ) liquid or solid media was used for all cloning procedures.

\section{$\mathrm{KCl}$ gradient analyses}

Some $3 \times 10^{9}$ cells of strain YDL524 were resuspended in $10 \mathrm{~mL}$ of ice-cold buffer A500 (0.5 M KCl, $20 \mathrm{mM}$ Tris- $\mathrm{HCl}$ at $\mathrm{pH} 8.0$, $5 \mathrm{mM}$ MgAc, $0.2 \%$ Triton X-100, $1 \mathrm{mM}$ DTT) supplemented with a protease inhibitor cocktail (EDTA free, Roche) and 0.5 unit $/ \mu \mathrm{L}$ RNasin (Promega). Cells were broken in a "one-shot cell disrupter" (Constant Systems) set at 1.7 kbar. Extracts were clarified by centrifugation at $4^{\circ} \mathrm{C}$ in a Ti50.2 rotor (Beckman) at 25,000 rounds per min for $15 \mathrm{~min}$. Typically $7 \mathrm{~mL}$ of clarified extracts were loaded on a Poly-Prep chromatography column (Biorad) packed with $200 \mu \mathrm{L}$ of IgG-sepharose 6 fast flow (Amersham Biosciences) previously equilibrated with $10 \mathrm{~mL}$ ice-cold buffer A500. Loaded columns were incubated for $60 \mathrm{~min}$ at $4^{\circ} \mathrm{C}$ with gentle shaking. The columns were then washed with $80 \mathrm{~mL}$ of ice cold A500. Some $3 \times 0.5 \mathrm{~mL}$ followed by $3 \times 1 \mathrm{~mL}$ of buffers containing $20 \mathrm{mM}$ Tris- $\mathrm{HCl}$ ( $\mathrm{pH} 8.0$ ), $5 \mathrm{mM} \mathrm{MgAc}, 0.2 \%$ Triton X-100, $1 \mathrm{mM}$ DTT, and either $0.8 \mathrm{M}, 1 \mathrm{M}, 1.2 \mathrm{M}, 1.5 \mathrm{M}, 2 \mathrm{M}$, or $3 \mathrm{M} \mathrm{KCl}$ followed by a buffer containing $4 \mathrm{M} \mathrm{MgCl}_{2}, 20 \mathrm{mM}$ Tris- $\mathrm{HCl}(\mathrm{pH}$ 8.0), $0.1 \%$ NP40 were sequentially added to the IgG-sepharose resin and eluting fractions were collected.

The protein and RNA contents of aliquots of the input extract, initial flow through fraction, and the first three elution fractions obtained after addition of each $\mathrm{KCl}$ buffer were analyzed as follows. For protein analysis, $5 \mu \mathrm{L}$ of a given fraction were diluted with the appropriate buffer to obtain $50 \mu \mathrm{L}$ of a $50 \mathrm{mM}$ Tris- $\mathrm{HCl}$ (pH 8.0), 100 mM DTT, 2\% SDS, 0.1\% bromophenol blue, 10\% glycerol solution. Ten microliters of that solution were subjected to SDS-PAGE on a $13 \%$ polyacrylamide gel followed by Western blot analysis. For RNA analysis, $300 \mu \mathrm{L}$ MQ $\mathrm{H}_{2} \mathrm{O}, 5 \mu \mathrm{L}$ glycogen, and $400 \mu \mathrm{L}$ of a phenol:chloroform:isoamylalcohol mix (Life Technologies) were added to $100 \mu \mathrm{L}$ of each fraction. The samples were thoroughly mixed and centrifuged $5 \mathrm{~min}$ at $4^{\circ} \mathrm{C}, 14,000 \mathrm{~g}$ in a microcentrifuge (Eppendorf 5415D). From the aqueous phases, $360 \mu \mathrm{L}$ were recovered, thoroughly mixed with $400 \mu \mathrm{L}$ of a phenol:chloroform:isoamylalcohol mix (Life Technologies), and the samples were centrifuged $5 \mathrm{~min}$ at $4^{\circ} \mathrm{C}, 14,000 \mathrm{~g}$ in a microcentrifuge (Eppendorf 5415D). RNAs from $300 \mu \mathrm{L}$ of the aqueous phases were then precipitated with ethanol. The RNA pellets were washed with $70 \%$ ethanol and dried. RNAs from the initial extract and flow through fraction were resuspended in $200 \mu \mathrm{L} M Q \mathrm{H}_{2} \mathrm{O}$, RNAs from all other fractions in $20 \mu \mathrm{L}$ MQ $\mathrm{H}_{2} \mathrm{O}$. Ten microliters of each sample were subjected to denaturing acrylamide gel electrophoresis followed by Northern analysis.

\section{$\mathrm{MgCl}_{2}$ gradient analyses}

Extracts were prepared from $3 \times 10^{9}$ cells of strains YDL524 and YO346 as described in the " $\mathrm{KCl}$ gradient analysis" section except that buffer $\mathrm{A} 200(0.2 \mathrm{M} \mathrm{KCl}, 20 \mathrm{mM}$ Tris- $\mathrm{HCl}$ at $\mathrm{pH} 8.0,5 \mathrm{mM}$ MgAc, $0.2 \%$ Triton X-100, $1 \mathrm{mM} \mathrm{DTT)} \mathrm{was} \mathrm{used.} \mathrm{Typically} 8 \mathrm{ml}$ of clarified extracts were loaded on a Poly-Prep chromatography column (Biorad) packed with $200 \mu \mathrm{L}$ of IgG-sepharose 6 fast flow (Amersham Biosciences) previously equilibrated with $10 \mathrm{~mL}$ of ice-cold buffer A200. Loaded columns were incubated for $60 \mathrm{~min}$ at $4^{\circ} \mathrm{C}$ with gentle shaking. The columns were then washed with $80 \mathrm{~mL}$ of ice-cold A200. Then $0.2 \mathrm{~mL}$ and then $2 \times 0.5 \mathrm{~mL}$ followed by $3 \times 1 \mathrm{~mL}$ of buffers containing $20 \mathrm{mM}$ Tris- $\mathrm{HCl}(\mathrm{pH}$ 8.0), $0.1 \% \mathrm{NP} 40$, and either $0.5 \mathrm{M} \mathrm{MgCl}_{2}, 2 \mathrm{M} \mathrm{MgCl}_{2}$, or $4 \mathrm{M}$ $\mathrm{MgCl}_{2}$ were sequentially added to the IgG-sepharose resin and eluting fractions were collected. Protein and RNA contents of aliquots of the input extract, initial flow through fractions, and of the second, third, and fourth elution fractions obtained after addition of each $\mathrm{MgCl}_{2}$-containing buffer were analyzed as described in the " $\mathrm{KCl}$ gradient analyses" section.

\section{Purification of the Cbf5p-ZZ/Gar1p/Nop10p complex}

Some $3 \times 10^{9}$ cells of strains YDL524 were processed as described in the " $\mathrm{MgCl}_{2}$ gradient analyses" section. One hundred microliters of the second fraction collected after addition of buffer M4000 were dialyzed in a "slide-a-lyzer" dialysis cassette (3500 MWCO, Pierce) against $800 \mathrm{~mL} 30 \mathrm{mM}$ Tris- $\mathrm{HCl}$ (pH 7.4), $150 \mathrm{mM} \mathrm{KCl}$, $2 \mathrm{mM} \mathrm{MgCl}$, for $2 \mathrm{~h} 30 \mathrm{~min}$ at $4^{\circ} \mathrm{C}$, with gentle agitation. The dialyzed sample was then concentrated on a microcon $(10,000$ MWCO, Millipore), previously equilibrated with $30 \mathrm{mM}$ Tris- $\mathrm{HCl}$ ( $\mathrm{pH} 7.4$ ), $150 \mathrm{mM} \mathrm{KCl}, 2 \mathrm{mM} \mathrm{MgCl}_{2}$, by centrifuging $20 \mathrm{~min}$ at $4^{\circ} \mathrm{C}, 10,000 \mathrm{~g}$ in a microcentrifuge (Eppendorf 5415D).

\section{Western analyses}

Proteins from total extracts (depletion experiments) or obtained from chromatography fractions were separated on 12 or $13 \%$ polyacrylamide/SDS gels and transferred to hybond-C extra membranes (Amersham Biosciences). Gar1p, Nhp2p, and Nop10p were detected by use of rabbit polyclonal sera diluted 200-, 5000-, and 500 -fold, respectively. Nop1p was detected using purified rabbit anti-Xenopus fibrillarin antibodies. Cbf5p-ZZ, Cbf5p-TAP, and Nhp2p-ZZ were detected using rabbit PAP (Dako) diluted 10,000fold.

\section{Northern hybridizations}

Small RNAs were fractionated on $6 \%$ polyacrylamide/urea gels, transferred to positively charged nylon membranes (N-hybond +, Amersham Biosciences) and detected by hybridization with antisense oligodeoxynucleotide probes as described by Henras et al. (1998). The sequences of the probes used have been described by Henras et al. (1998, 2001).

\section{ACKNOWLEDGMENTS}

The gifts of plasmids pBS1479 from Dr. B. Séraphin (CNRS, Gif-sur-Yvette) and of strains YDL524 and YDL521 from Dr. D. Lafontaine (Université Libre de Bruxelles) are gratefully acknowledged. We thank A. Rivals for expert technical assistance, Y. de Préval for synthesis of oligonucleotides, and D. Villa for art work. We are thankful to members of the Ferrer laboratory for help and numerous discussions. A.H. was a recipient of a postgraduate fellowship from the Ligue Nationale contre le Cancer. This work was supported by the CNRS, the Université Paul Sabatier, grants from La Ligue Nationale contre le Cancer ("Equipe Labellisée") and the 
ACI program of the Ministère Délégué à la Recherche et aux Nouvelles Technologies.

Received May 5, 2004; accepted July 28, 2004.

\section{REFERENCES}

Atzorn, V., Fragapane, P., and Kiss, T. 2004. U17/snR30 is a ubiquitous snoRNA with two conserved sequence motifs essential for $18 \mathrm{~S}$ rRNA production. Mol. Cell. Biol. 24: 1769-1778.

Bachellerie, J.P. and Cavaillé, J. 1997. Guiding ribose methylation of rRNA. Trends Biochem. Sci. 22: 257-261.

Bachellerie, J.P., Cavaillé, J., and Hüttenhofer, A. 2002. The expanding snoRNA world. Biochimie 84: 775-790.

Balakin, A.G., Smith, L., and Fournier, M.J. 1996. The RNA world of the nucleolus: Two major families of small RNAs defined by different box elements with related functions. Cell 86: 823-834.

Beltrame, M. and Tollervey, D. 1992. Identification and functional analysis of two U3 binding sites on yeast pre-ribosomal RNA. EMBO J. 11: 1531-1542.

- 1995. Base pairing between U3 and the pre-ribosomal RNA is required for 18S rRNA synthesis. EMBO J. 14: 4350-4356.

Bortolin, M.L., Bachellerie, J.P., and Clouet-d'Orval, B. 2003. In vitro RNP assembly and methylation guide activity of an unusual box C/D RNA, cis-acting archaeal pre-tRNA(Trp). Nucleic Acids Res. 31: 6524-6535.

Bousquet-Antonelli, C., Henry, Y., Gélugne, J.P., Caizergues-Ferrer, M., and Kiss, T. 1997. A small nucleolar RNP protein is required for pseudouridylation of eukaryotic ribosomal RNAs. $Е M B O ~ J .16$ : 4770-4776.

Cahill, N.M., Friend, K., Speckmann, W., Li, Z.H., Terns, R.M., Terns, M.P., and Steitz, J.A. 2002. Site-specific cross-linking analyses reveal an asymmetric protein distribution for a box C/D snoRNP. EMBO J. 21: 3816-3828.

Cavaillé, J., Nicoloso, M., and Bachellerie, J.P. 1996. Targeted ribose methylation of RNA in vivo directed by tailored antisense RNA guides. Nature 383: 732-735.

Cavaillé, J., Buiting, K., Kiefmann, M., Lalande, M., Brannan, C.I., Horsthemke, B., Bachellerie, J.P., Brosius, J., and Hüttenhofer, A. 2000. Identification of brain-specific and imprinted small nucleolar RNA genes exhibiting an unusual genomic organization. Proc. Natl. Acad. Sci. 97: 14311-14316.

Clouet d'Orval, B., Bortolin, M.L., Gaspin, C., and Bachellerie, J.P. 2001. Box C/D RNA guides for the ribose methylation of archaeal tRNAs. The tRNATrp intron guides the formation of two ribosemethylated nucleosides in the mature tRNATrp. Nucleic Acids Res. 29: 4518-4529.

Darzacq, X., Jády, B.E., Verheggen, C., Kiss, A.M., Bertrand, E., and Kiss, T. 2002. Cajal body-specific small nuclear RNAs: A novel class of $2^{\prime}$-O-methylation and pseudouridylation guide RNAs. EMBO J. 21: 2746-2756.

Decatur, W.A. and Fournier, M.J. 2003. RNA-guided nucleotide modification of ribosomal and other RNAs. J. Biol. Chem. 278: 695-698.

Dennis, P.P., Omer, A., and Lowe, T. 2001. A guided tour: Small RNA function in Archaea. Mol. Microbiol. 40: 509-519.

Dez, C., Noaillac-Depeyre, J., Caizergues-Ferrer, M., and Henry, Y. 2002. Naf1p, an essential nucleoplasmic factor specifically required for accumulation of box H/ACA small nucleolar RNPs. Mol. Cell. Biol. 22: 7053-7065.

Dragon, F., Pogačić, V., and Filipowicz, W. 2000. In vitro assembly of human H/ACA small nucleolar RNPs reveals unique features of U17 and telomerase RNAs. Mol. Cell. Biol. 20: 3037-3048.

Fatica, A., Dlakic, M., and Tollervey, D. 2002. Naf1 p is a box H/ACA snoRNP assembly factor. RNA 8: 1502-1514.

Filipowicz, W. and Pogačić, V. 2002. Biogenesis of small nucleolar ribonucleoproteins. Curr. Opin. Cell Biol. 14: 319-327.

Ganot, P., Bortolin, M.L., and Kiss, T. 1997a. Site-specific pseudouridine formation in preribosomal RNA is guided by small nucleolar
RNAs. Cell 89: 799-809.

Ganot, P., Caizergues-Ferrer, M., and Kiss, T. 1997b. The family of box ACA small nucleolar RNAs is defined by an evolutionarily conserved secondary structure and ubiquitous sequence elements essential for RNA accumulation. Genes \& Dev. 11: 941-956.

Ganot, P., Jády, B.E., Bortolin, M.L., Darzacq, X., and Kiss, T. 1999. Nucleolar factors direct the 2'-O-ribose methylation and pseudouridylation of U6 spliceosomal RNA. Mol. Cell. Biol. 19: 6906-6917.

Gautier, T., Bergès, T., Tollervey, D., and Hurt, E. 1997. Nucleolar KKE/D repeat proteins Nop56p and Nop58p interact with Nop1p and are required for ribosome biogenesis. Mol. Cell. Biol. 17: 7088-7098.

Girard, J.P., Lehtonen, H., Caizergues-Ferrer, M., Amalric, F., Tollervey, D., and Lapeyre, B. 1992. GAR1 is an essential small nucleolar RNP protein required for pre-rRNA processing in yeast. EMBO J. 11: $673-682$.

Henras, A., Henry, Y., Bousquet-Antonelli, C., Noaillac-Depeyre, J., Gélugne, J.P., and Caizergues-Ferrer, M. 1998. Nhp2p and Nop10p are essential for the function of H/ACA snoRNPs. EMBO J. 17: 7078-7090.

Henras, A., Dez, C., Noaillac-Depeyre, J., Henry, Y., and CaizerguesFerrer, M. 2001. Accumulation of H/ACA snoRNPs depends on the integrity of the conserved central domain of the RNA-binding protein Nhp2p. Nucleic Acids Res. 29: 2733-2746.

Hoang, C. and Ferre-D'Amare, A.R. 2001. Cocrystal structure of a tRNA Psi55 pseudouridine synthase: Nucleotide flipping by an RNA-modifying enzyme. Cell 107: 929-939.

Hughes, J.M. and Ares Jr., M. 1991. Depletion of U3 small nucleolar RNA inhibits cleavage in the $5^{\prime}$ external transcribed spacer of yeast pre-ribosomal RNA and impairs formation of $18 \mathrm{~S}$ ribosomal RNA. EMBO J. 10: 4231-4239.

Jády, B.E. and Kiss, T. 2001. A small nucleolar guide RNA functions both in 2'-O-ribose methylation and pseudouridylation of the U5 spliceosomal RNA. EMBO J. 20: 541-551.

Jády, B.E., Darzacq, X., Tucker, K.E., Matera, A.G., Bertrand, E., and Kiss, T. 2003. Modification of Sm small nuclear RNAs occurs in the nucleoplasmic Cajal body following import from the cytoplasm. EMBO J. 22: 1878-1888.

Kiss, T. 2001. Small nucleolar RNA-guided post-transcriptional modification of cellular RNAs. EMBO J. 20: 3617-3622.

. 2002. Small nucleolar RNAs: An abundant group of noncoding RNAs with diverse cellular functions. Cell 109: 145-148.

Kiss-László, Z., Henry, Y., Bachellerie, J.P., Caizergues-Ferrer, M., and Kiss, T. 1996. Site-specific ribose methylation of preribosomal RNA: A novel function for small nucleolar RNAs. Cell 85: 1077-1088.

Kiss-László Z., Henry, Y., and Kiss, T. 1998. Sequence and structural elements of methylation guide snoRNAs essential for site-specific ribose methylation of pre-rRNA. EMBO J. 17: 797-807.

Kiss, A.M., Jády, B.E., Darzacq, X., Verheggen, C., Bertrand, E., and Kiss, T. 2002. A Cajal body-specific pseudouridylation guide RNA is composed of two box H/ACA snoRNA-like domains. Nucleic Acids Res. 30: 4643-4649.

Kuhn, J.F., Tran, E.J., and Maxwell, E.S. 2002. Archaeal ribosomal protein L7 is a functional homolog of the eukaryotic $15.5 \mathrm{kD} /$ Snu13p snoRNP core protein. Nucleic Acids Res. 30: 931-941.

Lafontaine, D.L. and Tollervey, D. 1999. Nop58p is a common component of the box $\mathrm{C}+\mathrm{D}$ snoRNPs that is required for snoRNA stability. RNA 5: 455-467.

. 2000. Synthesis and assembly of the box C+D small nucleolar RNPs. Mol. Cell. Biol. 20: 2650-2659.

Lafontaine, D.L., Bousquet-Antonelli, C., Henry, Y., Caizergues-Ferrer, M., and Tollervey, D. 1998. The box H + ACA snoRNAs carry Cbf5p, the putative rRNA pseudouridine synthase. Genes \& Dev. 12: $527-537$.

Li, H.D., Zagorski, J., and Fournier, M.J. 1990. Depletion of U14 small nuclear RNA (snR128) disrupts production of $18 \mathrm{~S}$ rRNA in Saccharomyces cerevisiae. Mol. Cell. Biol. 10: 1145-1152.

Liang, W.Q. and Fournier, M.J. 1995. U14 base-pairs with 18S rRNA: A novel snoRNA interaction required for rRNA processing. Genes \& Dev. 9: 2433-2443. 
Liang, X.H., Liu, L., and Michaeli, S. 2001. Identification of the first trypanosome H/ACA RNA that guides pseudouridine formation on rRNA. J. Biol. Chem. 276: 40313-40318.

Liang, X.H., Xu, Y.X., and Michaeli, S. 2002. The spliced leader-associated RNA is a trypanosome-specific $\operatorname{sn}(0)$ RNA that has the potential to guide pseudouridine formation on the SL RNA. RNA 8: $237-246$.

Lyman, S.K., Gerace, L., and Baserga, S.J. 1999. Human Nop5/Nop58 is a component common to the box $\mathrm{C} / \mathrm{D}$ small nucleolar ribonucleoproteins. RNA 5: 1597-1604.

Marmier-Gourrier, N., Clery, A., Senty-Ségault, V., Charpentier, B., Schlotter, F., Leclerc, F., Fournier, R., and Branlant, C. 2003. A structural, phylogenetic, and functional study of $15.5-\mathrm{kD} / \mathrm{Snu} 13$ protein binding on U3 small nucleolar RNA. RNA 9: 821-838.

Mitchell, J.R., Wood, E., and Collins, K. 1999. A telomerase component is defective in the human disease dyskeratosis congenita. $\mathrm{Na}$ ture 402: 551-555.

Morrissey, J.P. and Tollervey, D. 1993. Yeast snR30 is a small nucleolar RNA required for $18 \mathrm{~S}$ rRNA synthesis. Mol. Cell. Biol. 13: 24692477.

Newman, D.R., Kuhn, J.F., Shanab, G.M., and Maxwell, E.S. 2000. Box C/D snoRNA-associated proteins: Two pairs of evolutionarily ancient proteins and possible links to replication and transcription. RNA 6: 861-879.

Ni, J., Tien, A.L., and Fournier, M.J. 1997. Small nucleolar RNAs direct site-specific synthesis of pseudouridine in ribosomal RNA. Cell 89: 565-573.

Niewmierzycka, A. and Clarke, S. 1999. S-Adenosylmethionine-dependent methylation in Saccharomyces cerevisiae. Identification of a novel protein arginine methyltransferase. J. Biol. Chem. 274: 814-824.

Omer, A.D., Ziesche, S., Ebhardt, H., and Dennis, P.P. 2002. In vitro reconstitution and activity of a C/D box methylation guide ribonucleoprotein complex. Proc. Natl. Acad. Sci. 99: 5289-5294.

Omer, A.D., Ziesche, S., Decatur, W.A., Fournier, M.J., and Dennis, P.P. 2003. RNA-modifying machines in archaea. Mol. Microbiol. 48: 617-629.

Peculis, B.A. 1997. The sequence of the $5^{\prime}$ end of the U8 small nucleolar RNA is critical for $5.8 \mathrm{~S}$ and $28 \mathrm{~S}$ rRNA maturation. Mol. Cell. Biol. 17: 3702-3713.

Peculis, B.A. and Steitz, J.A. 1993. Disruption of U8 nucleolar snRNA inhibits $5.8 \mathrm{~S}$ and $28 \mathrm{~S}$ rRNA processing in the Xenopus oocyte. Cell 73: 1233-1245.

Pogačić, V., Dragon, F., and Filipowicz, W. 2000. Human H/ACA small nucleolar RNPs and telomerase share evolutionarily conserved proteins NHP2 and NOP10. Mol. Cell. Biol. 20: 9028-9040.

Rashid, R., Aittaleb, M., Chen, Q., Spiegel, K., Demeler, B., and Li, H. 2003. Functional requirement for symmetric assembly of archaeal box C/D small ribonucleoprotein particles. J. Mol. Biol. 333: 295-306.

Richard, P., Darzacq, X., Bertrand, E., Jády, B.E., Verheggen, C., and Kiss, T. 2003. A common sequence motif determines the Cajal body-specific localization of box H/ACA scaRNAs. EMBO J. 22: 4283-4293.

Rigaut, G., Shevchenko, A., Rutz, B., Wilm, M., Mann, M., and Séraphin, B. 1999. A generic protein purification method for protein complex characterization and proteome exploration. Nat. Biotechnol. 17: 1030-1032.

Rozhdestvensky, T.S., Tang, T.H., Tchirkova, I.V., Brosius, J., Bachellerie, J.P., and Hüttenhofer, A. 2003. Binding of L7Ae protein to the K-turn of archaeal snoRNAs: A shared RNA binding motif for C/D and H/ACA box snoRNAs in Archaea. Nucleic Acids Res. 31: 869-877.

Smith, C.M. and Steitz, J.A. 1997. Sno storm in the nucleolus: New roles for myriad small RNPs. Cell 89: 669-672.

Szewczak, L.B., DeGregorio, S.J., Strobel, S.A., and Steitz, J.A. 2002. Exclusive interaction of the $15.5 \mathrm{kD}$ protein with the terminal box C/D motif of a methylation guide snoRNP. Chem. Biol. 9: 1095-1107.

Tang, T.H., Bachellerie, J.P., Rozhdestvensky, T., Bortolin, M.L., Huber, H., Drungowski, M., Elge, T., Brosius, J., and Hüttenhofer, A. 2002. Identification of 86 candidates for small non-messenger
RNAs from the archaeon Archaeoglobus fulgidus. Proc. Natl. Acad. Sci. 99: 7536-7541.

Terns, M.P. and Terns, R.M. 2002. Small nucleolar RNAs: Versatile trans-acting molecules of ancient evolutionary origin. Gene Expr. 10: $17-39$.

Tollervey, D. 1987. A yeast small nuclear RNA is required for normal processing of pre-ribosomal RNA. EMBO J. 6: 4169-4175.

Tollervey, D., Lehtonen, H., Carmo-Fonseca, M., and Hurt, E.C. 1991. The small nucleolar RNP protein NOP1 (fibrillarin) is required for pre-rRNA processing in yeast. EMBO J. 10: 573-583.

Tran, E.J., Zhang, X., and Maxwell, E.S. 2003. Efficient RNA 2'-Omethylation requires juxtaposed and symmetrically assembled archaeal box C/D and $C^{\prime} / \mathrm{D}^{\prime}$ RNPs. EMBO J. 22: 3930-3940.

Tyc, K. and Steitz, J.A. 1989. U3, U8 and U13 comprise a new class of mammalian snRNPs localized in the cell nucleolus. $E M B O \mathrm{~J} . \mathbf{8}$ : 3113-3119.

Tycowski, K.T., Shu, M.D., and Steitz, J.A. 1994. Requirement for intron-encoded U22 small nucleolar RNA in 18S ribosomal RNA maturation. Science 266: 1558-1561.

Tycowski, K.T., Smith, C.M., Shu, M.D., and Steitz, J.A. 1996. A small nucleolar RNA requirement for site-specific ribose methylation of rRNA in Xenopus. Proc. Natl. Acad. Sci. 93: 14480-14485.

Tycowski, K.T., You, Z.H., Graham, P.J., and Steitz, J.A. 1998. Modification of U6 spliceosomal RNA is guided by other small RNAs. Mol. Cell 2: 629-638.

Wang, C. and Meier, U.T. 2004. Architecture and assembly of mammalian H/ACA small nucleolar and telomerase ribonucleoproteins. EMBO J. 23: 1857-1867.

Wang, C., Query, C.C., and Meier, U.T. 2002. Immunopurified small nucleolar ribonucleoprotein particles pseudouridylate rRNA independently of their association with phosphorylated Nopp140. Mol. Cell. Biol. 22: 8457-8466.

Watkins, N.J., Gottschalk, A., Neubauer, G., Kastner, B., Fabrizio, P., Mann, M., and Lührmann, R. 1998a. Cbf5p, a potential pseudouridine synthase, and Nhp2p, a putative RNA-binding protein, are present together with Garlp in all H BOX/ACA-motif snoRNPs and constitute a common bipartite structure. RNA 4: 1549-1568.

Watkins, N.J., Newman, D.R., Kuhn, J.F., and Maxwell, E.S. 1998b. In vitro assembly of the mouse U14 snoRNP core complex and identification of a 65-kDa box C/D-binding protein. RNA 4: 582-593.

Watkins, N.J., Ségault, V., Charpentier, B., Nottrott, S., Fabrizio, P., Bachi, A., Wilm, M., Rosbash, M., Branlant, C., and Lührmann, R. 2000. A common core RNP structure shared between the small nucleoar box C/D RNPs and the spliceosomal U4 snRNP. Cell 103: $457-466$.

Watkins, N.J., Dickmanns, A., and Lührmann, R. 2002. Conserved stem II of the box C/D motif is essential for nucleolar localization and is required, along with the $15.5 \mathrm{~K}$ protein, for the hierarchical assembly of the box C/D snoRNP. Mol. Cell. Biol. 22: 8342-8352.

Weinstein, L.B. and Steitz, J.A. 1999. Guided tours: From precursor snoRNA to functional snoRNP. Curr. Opin. Cell Biol. 11: 378-384.

Wu, P., Brockenbrough, J.S., Metcalfe, A.C., Chen, S., and Aris, J.P. 1998. Nop5p is a small nucleolar ribonucleoprotein component required for pre-18 S rRNA processing in yeast. J. Biol. Chem. 273: 16453-16463.

Yang, Y., Isaac, C., Wang, C., Dragon, F., Pogačić, V., and Meier, U.T. 2000. Conserved composition of mammalian box H/ACA and box $\mathrm{C} / \mathrm{D}$ small nucleolar ribonucleoprotein particles and their interaction with the common factor Nopp140. Mol. Biol. Cell 11:567-577.

Yang, P.K., Rotondo, G., Porras, T., Legrain, P., and Chanfreau, G. 2002. The Shq1p.Naf1p complex is required for box H/ACA small nucleolar ribonucleoprotein particle biogenesis. J. Biol. Chem. 277: 45235-45242.

Zebarjadian, Y., King, T., Fournier, M.J., Clarke, L., and Carbon, J. 1999. Point mutations in yeast CBF5 can abolish in vivo pseudouridylation of rRNA. Mol. Cell. Biol. 19: 7461-7472.

Zhou, H., Chen, Y.Q., Du, Y.P., and Qu, L.H. 2002. The Schizosaccharomyces pombe mgU6-47 gene is required for 2'-O-methylation of U6 snRNA at A41. Nucleic Acids Res. 30: 894-902. 

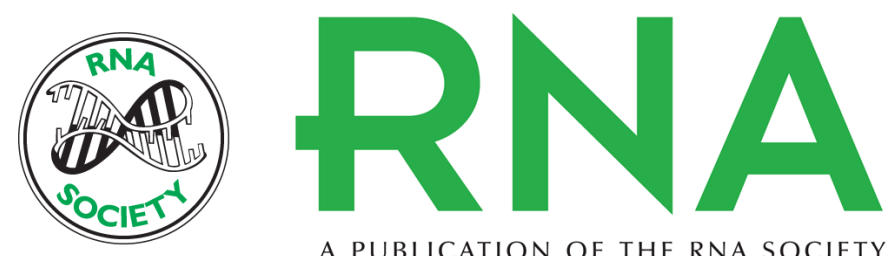

A PUBLICATION OF THE RNA SOCIETY

\section{Cbf5p, the putative pseudouridine synthase of H/ACA-type snoRNPs, can form a complex with Gar1p and Nop10p in absence of Nhp2p and box H/ACA snoRNAs}

ANTHONY K. HENRAS, REGINE CAPEYROU, YVES HENRY, et al.

RNA 2004 10: 1704-1712

References This article cites 82 articles, 45 of which can be accessed free at:

http://rnajournal.cshlp.org/content/10/11/1704.full.html\#ref-list-1

License

Email Alerting Receive free email alerts when new articles cite this article - sign up in the box at the

Service top right corner of the article or click here. 